\title{
Divination expressed through poetry: The divinatory poems of Johannes Mokgwadi
}

\author{
M.J. Mojalefa \\ Department of African Languages, \\ University of Pretoria, 0002, Pretoria, South Africa \\ jerry.mojalefa@up.ac.za
}

\begin{abstract}
This article aims to explore the divinatory poems of Johannes Mokgwadi with special reference to their structure, role and tools of performance in the art of divination as practised still today by the Bapedi in some rural areas of South Africa. Cultural verse forms in 'the poetry of divinatory bones', as this form of poetry may be called (due to the set of divinatory bones used in the process of divination), will be outlined through a discussion of metrical compositions, long-measure verse, long-measure 'echo' or repetition verse, divinatory poems with linked hemistichs, divinatory poems with repeated segments, long-measure triplet verse, and verses of four, five or more hemistichs. These form designs are intended to achieve maximum impact when recited. The role of the traditional healer as an intermediary figure between the gods and his people will be indicated. Divinatory poems are shrouded in secrecy, as they are intended for listening (by targeted addressees) and not for reading (by the general public), for communication with ancestors and not for performance before an audience in public gatherings. The discussion of the divinatory apparatus serves to shed light on the symbolism of the key icons in the selected extracts from the poetry.
\end{abstract}

\section{Introduction}

Although praise poetry by black South Africans has received some critical attention, there are still several researchers (discussed below), who find it difficult to understand the structure of this poetic form. Opland (1983:159), for example, assumes that every poem has to have a structure similar to that of poetry written in one of the languages of the West, such as English, and finds the absence of such structure in praise poetry worrying. The same criticism that is raised by Opland, writing on isiXhosa oral poetry, is also voiced by some critics (e.g. Rycroft, 1960) with regard to modern Sepedi ${ }^{1}$ poetry, saying that it is no longer oral, but rather written, and so should have more in common with Western poetry. However, Groenewald (1993:12-31) states the opposite view, namely, that traditional oral and modern written Sepedi poetry are similar in many respects to each other and to Western modes (especially where the Western mode in question is that of oral Anglo-Saxon poetry), differing only in content, as this article attempts to show.

Comparable to Anglo-Saxon alliterative verse, African oral poetry is largely divorced from meter, where meter is defined in terms of the recurrence of stressed and unstressed syllables. African languages in general, and poetry in the African languages in particular, are not characterized by stress, but rather by such aspects as tone, length, patterns of repetition, and unusual grammar (Shipley, 1972:102).

The poems of Johannes Mokgwadi have been selected to explore the variety of verse forms in Sepedi poetry of divination. In brief, Johannes Mokgwadi is known as a harp-player, lyricist, composer and arranger of traditional songs. Many of his lyrics were recorded on compact discs. He is also renowned for his divinatory poetry. So far, he is the only divinatory poet who has rendered the shortest divinatory poems in Sepedi oral works.

The role of the diviner as poet will be explored in this article, as well as the apparatus that is used in the art of divination, particularly as it is still practised today by the Bapedi in the Limpopo Province of the Republic of South Africa, in order to elucidate the central iconography:

During the examination of a patient, communication between the diviner and his/her ancestors or the patient's ancestors is established through a form of praise poetry, known as the poetry of divination. During this process 
different divinatory bones play a pivotal role in the creation of a particular 'prayer', which takes the form of a recitation. Consequently, in order to properly ground this poetic form, a description of the divinatory apparatus, consisting of the principal knuckle bones (dipheko/ditaola) and a few totemic bones of the divinatory set of ditaola will follow the discussion of the verse form.

\section{Verse forms}

In poetry, whether Western or African, verse design underlies the form of any single line of verse (or single verse instance, using poetical terminology). This determines the invariant features of the verse instances and sets up the limits of variations (Jakobson in Sebeok, 1960:373). The completed literary composition does not betray many signs of the effort that went into its creation. This rounded-off composition might be ascribed to an organic structure, that is, to a structure which appears to be entirely natural and spontaneous, the elements composing it all fused together into one natural and harmonious whole. These elements combine to communicate the thoughts and feelings that lie behind the words (Heese \& Lawton, 1983:11).

There is a rhythm in the lines of a poem, just as there is a rhythm of the poem as a whole. This becomes clearer where the poem is written in stanzas, and groups of lines recur in the same pattern. Form does not only consist of rhythmic patterns, such as stanzas; there may be an observable pattern of symbols, or a specific language structure (Simpson, 1972:5). Most traditional African poems, however, are not divided into stanzas, but there are quite a number of different verse forms in use in Sepedi poetry such as Di wele mohlakola (Mashilo, Mohlamonyane \& Maripane, 1998:86). The composer of traditional praise poems knows no parts, stanzas or lines in his composition. In Brooks and Warren's (1976:525) examination of stanzaic forms in English poetry they observe that:

any given type of stanza must be regarded as an instrument at the poet's disposal and not as a thing important in itself.

Furthermore, they argue that the same creation may be employed for different purposes. Therefore, any given type of verse is used in conjunction with many other poetic factors. A reader should, therefore, be wary of attributing special effects to special verse forms. Considering only the stanzaic form in isolation from other poetic elements may lead to the most general of conclusions. The above comment is applicable to the Sepedi divinatory composition of poetic art.

Form designs in the poetry of divinatory bones are, to a large extent, bound up with what they were intended for, as well as the manner in which they were recited. Divinatory poems are definitely intended for the ear (listening) and not the eye (reading), for communication with the ancestors and not for performance before an audience in public gatherings. For this reason, the conveyance of thought and action, embellished in various stylistic ways, is uppermost because such thoughts and actions are conveyed in the form of prayer rather than entertainment.

Cultural verse designs in Sepedi poetry of divinatory bones will be discussed under the following subheadings, as articulated by Groenewald (1993):

- Metrical compositions

- Long-measure verse

- Long-measure repetition verse

- Divinatory poems with linked hemistichs

- Divinatory poems with repeated segments

- Long-measure triplet verse

- Verses of four, five or more hemistichs

In the discussion of cultural verse forms, only a few examples of divinatory compositions (one poem per category) are cited. 


\section{Metrical composition}

Hymes (in Sebeok, 1960:125) and de Groot (1946:19-20) discuss meter as a balanced unified build-up pattern. Thus, meter may be described as a repetitive and symmetrical pattern of stressed and unstressed syllables on which a poem may be based (Heese \& Lawton, 1983:13). According to Groenewald (1993:34), Sepedi meter differs from the above definitions, more especially with regard to the issue of equation (the balance of the number of rhythmical summits and syllables per hemistich). For instance, rhyme has not been formally used as the way of defining Sepedi meter. What matters is the arrangement of the elements of the poetic language, such as the sounds of the language, the tone that controls syllables, and the phoneme that determines rhythm, including word stem and phrase. Accordingly, this article examines Sepedi meter as discussed by Groenewald, emphasizing that the issue of equation is not considered in this type of arrangement.

\section{Arrangement of the elements of the poetic language and the division of the metrical line into hemistichs}

The arrangement of the elements of the poetic language and the division of the metrical line(s) into hemistichs (discussed as equal metrical units/parts by Brown, 1966:137) will be argued separately to illustrate that this type of arrangement occurs often in the poetry of traditional healers (dingaka). However, it cannot be disputed that it is the characteristic metrical mould of some of the Sepedi forms of divinatory poems.

The poems which are quoted are accompanied by literal translations.

What follows is an example of the poetry accompanying the art of divination showing the specific arrangement of the elements of the Sepedi language and the division of the metrical lines into hemistichs. Johannes Mokgwadi (sound recording, 1999) recites Selomi ${ }^{2}$ as follows:

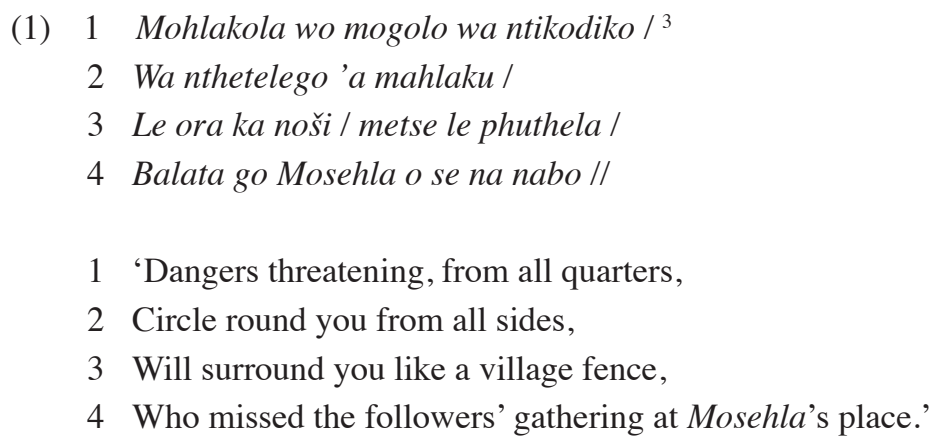

The aim is not to discuss the whole poem, but only to indicate the specific arrangement of the poetic elements.

In line 3 , there is a summit at which the pause naturally occurs in the middle of the line:

(2) 3 Le ora ka noši / metse le phuthela /

'Will surround you like a village fence,'

Even in the English translation, a natural pause divides this line into two equal parts (hemistichs). The boundary indicated by (/) in line 3 above can be called a division boundary or caesura.

To show these two hemistichs clearly, the line can be restructured as follows:

(3) Le ora ka noši

and

metse le phuthela 
This line is made up of an arranged pattern of rhythmical summits that goes hand-in-hand with its syllabic pattern.

This is illustrated as follows:

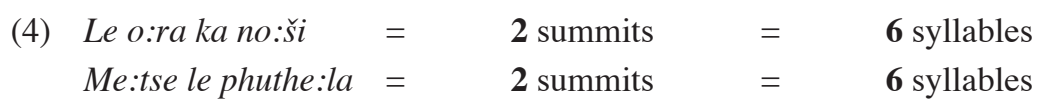

It will be noticed that the number of rhythmical summits and syllables are equal, that is, there are two summits and six syllables per hemistich. This type of the poetic language arrangement occurs often in the poetry of traditional healers (dingaka).

\section{Short and long lines in a verse}

The following poem, Sehlako, is recited by Johannes Mokgwadi (sound recording, 1999) in his divinatory practice:

(5) Sehlako ke motho, sehlako mmele a motho,

Sehlako Mmirwa ke Tlou ${ }^{4}$

Ge e le go hlabja ka kotse o hlabilwe,

Mootlwa o ile wa hlaba Barolong,

Babirwa ba kwa bose,

Ba re:

Agee, Sehlako o hlabilwe!

Segela mogolo kwekwetla, gomme a kgopše a we nayo.

'Sehlako is a man; a shield is a body of man,

The elephant is Mmirwa's shield,

The shield once pierced, he too is pierced,

But a thorn did prick the Barolong,

The Babirwa enjoyed it

And then did

Shout with joy saying praise be to Sehlako.

Cut a clumsy pair of shoes for your elder, and you will see him slip and fall.'

Tonal rhymes will not be discussed in this poem. There are eight metrical lines in this verse. This strophe is structured in such a way that it consists of some short lines, for example:

(6) Sehlako Mmirwa ke Tlou,

Babirwa ba kwa bose,

Ba re:

and some long lines, such as:

(7) Sehlako ke motho, sehlako mmele a motho,

Ge e le go hlabja ka kotse o hlabilwe,

Segela mogolo kwekwetla, gomme a kgopše a we nayo.

These metrical lines indicate the difference of rhythm employed by the poet. Divinatory poems are usually structured in such a way that they consist of some short and long lines to indicate different tempos employed in such metrical lines. 


\section{Long-measure verse}

Long-measure verse is also the characteristic metrical mould of some of the Sepedi forms of divinatory poems. They consist of a single metrical line or strophe that is divided medially by a natural pause or "caesura', which divides the strophe into two equal hemistichs.

For instance, in his divination, Johannes Mokgwadi (sound recording, 1999) recites Moremogolo ${ }^{5}$ as follows:

(8) More wo mogolo wa mafala! /

Ke fadile, / la mopo ke boa nalo.

'I am the mighty tree of heroes!

My anger is aroused; I will be forced to retaliate.'

The above two lines are divided by a natural pause (caesura) indicated by (/) for a rest at the end of the first line to form a strophe (single metrical line). Even though the number of syllables and symmetrical summits are not equal in this strophe, this does not disqualify the existence of the meter of this poem. Metrical variants such as parallelism (a line having a relation with another) are also a determining factor. Furthermore, it can be observed that the above two lines do not rhyme as would be expected of this type of poem in Western style poetry. Instead, they are joined together to form a strong unit similar to a couplet, as is displayed by fadile to the left in the second line. The latter example is the exact repetition/linking of a word (phrase), which is generally known as exact parallelism.

\section{Long-measure repetition verse}

According to Harries (1956:5), there is a device known to Persian poets as mukarrar, that is, the repetition or socalled 'echo' of a word or part of a word after the first hemistich. Swahili poets adopted this technique in quatrain verses. This technique is also evident in Sepedi divinatory poems. An interesting example of such a poem, recited by Johannes Mokgwadi (sound recording, 1999) is Legwame:

(9) Legwame la hlogo ye tšhweu / hlogo ye tšhweu e rwala diala;

Ga go sa tle dira / go tla tla tšie;

Ke lona moririmošweu / moririmošweu lehumo;

Ee, le ile bošweu / le ile bošweu la re boso.

'O dignity of silver-headed age! With precious trophies on his head adorned,

If armed men do not appear then the locust will come;

A proud possession is your silver hair, the silver hair the sign of wealth;

Yes, with tufts and tassles black and white.'

Note the 'echo' (linking) of a word (which can also be referred to as parallelism) after the first hemistich as structured in the second and third lines of the poem under discussion:

(10) Ga go sa tle dira / go tla tla tšie;

Ke lona moririmošweu / moririmošweu lehumo;

The words in bold in both hemistichs of each line, that is, tle and moririmošweu, are repeated words in these two lines and represent long-measure repetition verse. Even if the words tla/tle in:

Ga go sa tle dira / go tla tla tšie; 
were not repeated immediately after being used for the first time, as can be expected of the arrangement of longmeasure 'echo' verse, this type of arrangement can be considered a structured form of long-measure repetition verse because the repeated word $t a(e)$ is written toward the end of the first hemistich and then repeated in the middle of the second hemistich. The assumption is that the tle in the first hemistich and the tla in the second hemistich also represent long-measure repetition verse, as they are arranged in such a way as not to be far from each other in the line. In other words, they are placed fairly close to each other in the middle of the metrical line.

There is, moreover, an 'echo' of a phrase after the first hemistich:

(11) Legwame la hlogo ye tšhweu / hlogo ye tšhweu e rwala diala; Ee, le ile bošweu / le ile bošweu la re boso.

Both phrases:

(12) hlogo ye tšhweu

and

le ile bošweu

would also have been considered long-measure ‘echo' verse by the Persian poets, although Harries (1956:5) does not discuss this type of arrangement under long-measure repetition verse. One can insist on including this arrangement under this type of verse, because the repetition of a word or part of a word after the first hemistich does not differ from the 'echo' of a phrase after the first hemistich. The repeated syntactic units, as shown above, play an important role in linking the essential ideas of the poem.

\section{Divinatory poems with linked hemistichs}

Parallelism can be described as linguistic similarities that may be observed between certain metrical lines: '... a certain similarity between two parts or members of a sentence whose words (phrases) correspond to one another' (Guma, 1967:159). It is the construction of a sentence using repeated syntactic units. Poems in which successive verses are linked together by the repetition in each successive verse of a terminal measure of the preceding verse, are popular in Sepedi divinatory poetry. The following poem, Thakadu, is an example of this type:

(13) Thakadu a ntopa, a ntopa,

Motse ka lopa ke badimo,

Badimo batho ba kopi 'a morara' Senamela,

Senamela senyabuhla senyaphokeng.

'The antbear picked me up, and picked me up.

By the hut, I have been hooked by the ancestors,

The ancestors that are people of Senamela who is cunning,

Senamela, the careless and filthy person.'

The words, badimo and Senamela can be ascribed to parallelism, which may be further described as (exact) left linking, because they link metrical lines to the left. This syntactic device was adopted by Sepedi divinatory poets and bears out the notion that metrical lines are like strings of pearls in a necklace, as shown above in the poem. The poet uses this strategy to indicate how the ancestors (badimo) play a prominent role in the spiritual lives of the Bapedi (Senamela). 


\section{Divinatory poems with repeated segments}

In this article poems, in which one or more strophes, or the whole or part of a word is repeated within each verse, are termed diretomosehlwana (poems with repeated segments or parallelism). This technique takes on several structural forms, which are regarded as a type of 'poetic acrobatics' (Harries, 1956:8) employed by the poet to indicate his/her skill in designing strophes in a poem. A hemistich may be repeated either simply or in reverse. Johannes Mokgwadi (sound recording, 1999) employs this technique in his divinatory poems, as can be seen in the poem Lešata ke la mogodi that follows:

(14) Ke mabje a lešata / ke lešagašaga la molapo,

Lešata ke la mogodi 'a tšie / šatana la bomogolodi,

Sa lešata ga se sa lešata / sa lerole ke sa lerole,

Sa lerole ke sa lerole / legoa go goa notwane,

Ga le na legoa kudu / go hwa kgoši,

Kgoši e hwa ka mabje a lerole / lešata ke la mabje.

'This is unbearable noise of stones in the valley,

Noise like that of locust catchers; small noise of the battle,

That makes noise is not noisy, and that makes dust is of dust,

That makes dust is of dust, as this is the noise made by the hammer,

Dust does not make too much noise, as it is like the death of a chief,

The chief's death is predicted by the rolling of stones.'

The hemistich, which is repeated, simply is sa lerole ke sa lerole; and the hemistich, lešata ke la mabje, from the first line, is repeated in reverse in the last line of the poem. Here again, the poet employs a similar strategy/technique to show his skill in designing the strophe in this poem to highlight the importance of divination in the lives of the Bapedi.

\section{Long-measure triplet verse}

Long-measure triplet verse forms may be found in Sepedi divinatory poems. What is usually common is that they lack rhyming hemistichs. It is not surprising that rhyme is missing in this form, because rhyme is one of the devices that is rarely used in Sepedi traditional poetry. The following poem, Makgolela, is an example of form without rhyme (Mokgwadi, sound recording, 1999):

(15) Ke lekgolela la seša / sekgopša sa dingaka,

Ge ke kgopilwe / ke wela ntlong,

Ga ke wele ntle / ke se mošemanyana.

'I can force my way out, for I can entice the doctors

If I have been hooked, I fell on the hut,

I do not fall out, because I am not a baby boy.'

Mokgwadi accepts that rhyme is one of the devices that are rarely used in Sepedi divinatory poetry. As a result, he emphasizes that divinatory poems are not determined by rhyme at all.

\section{Verses of four, five or more hemistichs}

Within the quatrain, a single verse of a Sepedi divinatory poem usually consists of two lines. A verse of four hemistichs is written either as a single metrical line or as two metrical lines. Rhyming is not evident in this form. 
For this article, only two poems having different lines recited by Johannes Mokgwadi (sound recording, 1999), are quoted:

(16a) Tibula

Ke Tibula 'a pitsi 'a Mogwadi,

Ba dimogile Bangwaketse; /

Batho ba Mokubela' Moraka,

Ke bona ba sehlogo sa ngaka. //

'The hoof (Tibula) of zebra-ox (Mogwadi),

The Bangwaketse have been overthrown;

These are people of Moraka,

These are people who are made cruel by the witchdoctor.'

(16b) Legwame

Legwame le lemerwalo,

Le lemerwalo ya boTlapo, /

E laditše Tlapo nageng, /

Gomme Tlapšane a goroga

Ka merwalo ye megolo ya boTlapo. //

'The knuckle bone Legwame is associated with freights,

These freights belong to Tlapo.

Tlapo, who suffered from hunger in the wilderness,

And then Tlapšane arrived home

With heavy loads of Tlapo's.'

On the one hand, poem (a) is divided into two metrical lines: that is, metrical line one is divided as follows:

(17) Ke Tibula 'a pitsi' a Mogwadi,

Ba dimogile Bangwaketse; /

and metrical line two is dented as follows:

(18) Batho ba Mokubela' Moraka,

Ke bona ba sehlogo sa ngaka. //

By contrast, poem (b) is structured differently from poem (a) in that metrical line one is recited as follows:

(19) Legwame le lemerwalo,

Le lemerwalo ya boTlapo, /

while metrical line two is recited as follows:

(20) E ladiť̌se Tlapo nageng, /

and the final metrical line (three) is structured as follows: 
(21) Gomme Tlapšane a goroga

Ka merwalo ye megolo ya boTlapo. //

Thus, poem (b) comprises three hemistichs of different length, while poem (a) comprises two equal hemistichs. It has been noticed that most Sepedi divinatory poems are structured in such a way that they consist of only one verse or stanza, although there are some which are divided into more verses.

To better comprehend the symbolism of the key icons in the selected extracts from the poetry, a full discussion of divinatory bones and processes follows before the closing remarks.

\section{Tools of the trade/divination}

\section{The divinatory apparatus}

The Bapedi believe in honouring their ancestors (badimo) even though the concept of God (Modimo or Kgobe) does exist in their religion, including the belief in everlasting life, that is, in life after death. Their ancestral worship is based on the belief that the living and the dead can mutually influence one another. Therefore, the badimo have to be honoured through thanksgiving and sacrifices ( $g$ o phasa) because they are the intermediaries of God (Modimo/Kgobe). The ancestral spirits are usually seen or heard at night, through dreams. To appease them, a traditional healer will be called to conduct a divining service. This ceremony requires particular divinatory apparatus, and the healer will recite a divining poem.

The pieces in the divining set are not exclusively bones, but, as most of the pieces are bones, it is perhaps permissible to speak collectively of bones for the sake of brevity (Eiselen, 1932:3). The divining set comprises a number of groups of items, namely:

(22a) a set of four entitled meetsemagolo/mawatle (sea shells) symbolizing two males (a large old man and a small young man); and two females (a large old woman and a small young woman)

(22b) a set of four cut horns of elephants or goats called ditlou, symbolizing two males (a large old man and a small young man) and two females (a large old woman and a small young woman)

(22c) a set of four carved cattle hoofs, representing in turn a big old man, a big old woman, a small young man and a small young woman; these are known as dipetlwa/ditlhako. Besides these, there are a number of additional sea shells, big ones representing old and young women, small ones representing baby girls or girls, and pointed ones, normally two, representing human voices.

Although Mojalefa (2000:12) refers to all the divining bones in an earlier discussion of the divinatory apparatus, this article is interested in showing the shape of the divinatory bones as in (b) and (c) above, because the two sets are similar in all facets, except size. These are given below.

\section{Large divinatory bones}
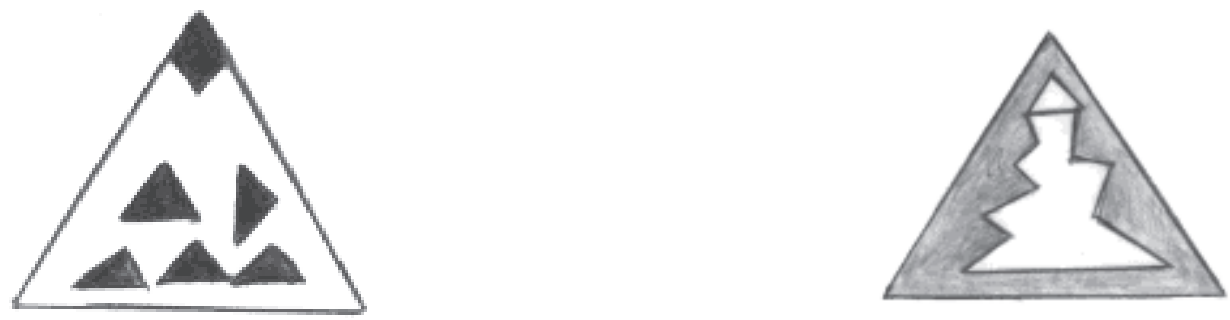
mmakgadi (cut horn of a he-goat)

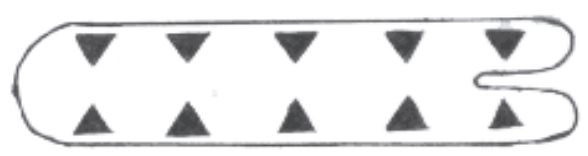

selomi (cut horn of a she-goat)

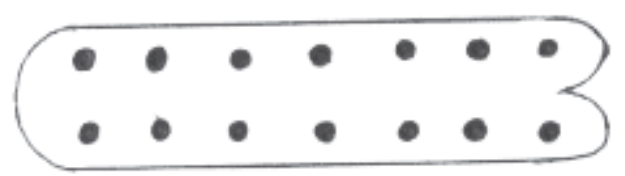

There are two main sets of divining bones in Sepedi divination, namely dipetlwa and ditlou. In the first set, as shown above, the pieces depicting the man and the woman are cut from the tip of the hoof of a bull and a cow respectively, as they represent gender, and are shaped pyramidically. Both pieces are decorated with small holes on one surface, while the piece representing the woman also has a cross-incised (though not indicated in the picture above) on this same surface for differentiation.

In addition to the two principal sets of bones, there are accessory bones. To divine by means of such bones is referred to as to laola.

\section{Smaller divining bones}

Within the bigger set of divinatory bones, there are four pieces of each of the smaller sets of divining cattle hoofs, goat/elephant horns and sea shells, without which divination is not possible. These divining pieces rule over all the other divining bones. They are read:

1. in accordance with the way they fall in relation to one another

2. by looking at the general position of one of the sets in relation to the divining bone serving to examine the patient

3. by examining the divining bone, male or female, depending on the gender of the patient.

\section{Totemic divining bones}

Most of the totemic divining bones are made from the uncooked knee bones of male and female herbivorous and carnivorous animals. These bones must be taken from animals that the diviners have killed themselves. A bone taken from a carcass rotting in the veld is quite useless for divination purposes. These bones are used to laola (divine) the patient according to his/her totemic clan. The male bone represents the men of a particular totemic clan and the female bone, the women. Sometimes a third bone may be added to represent their children.

The following is a list of some of the totemic divining bones contained within the larger set of Sepedi divining bones (dipheko). It should be noted that some of the divining bones are mentioned by name in the divinatory poems because they play a significant role in the examination of a patient:

\section{Herbivorous animals:}

\begin{tabular}{|l|l|l|}
\hline tlou & elephant & adult male and female and child \\
tholo & kudu & adult male and female \\
adult male and female and child \\
phuti & duiker & adult male and female \\
phudufudu(malope) & steenbok & adult male and female \\
kgomo (maseselle) & cattle & adult male and female \\
noko & porcupine & adult male and female \\
phala & impala & adult female only \\
nku $($ seromo $)$ & sheep & adult male and female \\
pudi & goat & adult male and female \\
kome & klipspringer & adult male only \\
tshephe & springbok & adult female only \\
serolo & bushbuck & adult male and female \\
kgama & hartebeest & adult male and female \\
letlabo & red buck & adult male and female and child \\
lekwena & reedbuck & \\
khudu & tortoise & \\
\hline
\end{tabular}


Carnivorous animals:

\begin{tabular}{|l|l|l|}
\hline $\begin{array}{l}\text { phiri } \\
\text { tau }\end{array}$ & $\begin{array}{l}\text { hyena } \\
\text { lion } \\
\begin{array}{l}\text { mp̌a } \\
\text { nkwe }\end{array}\end{array}$ & $\begin{array}{l}\text { adult male and female } \\
\text { adult male and female and child. (It represents a witch/wizard.) } \\
\text { adult male and female and child. } \\
\text { (It is tau's (lion's) instrument of destruction.) } \\
\text { adult male and female }\end{array}$ \\
\hline
\end{tabular}

Omnivorous animals:

\begin{tabular}{|l|l|l|}
\hline $\begin{array}{l}\text { tšhwene } \\
\text { kolobe }\end{array}$ & $\begin{array}{l}\text { baboon } \\
\text { pig }\end{array}$ & $\begin{array}{l}\text { adult male and female } \\
\text { adult male and female }\end{array}$ \\
\hline
\end{tabular}

Insectivorous animal:

\begin{tabular}{|l|l|l|}
\hline thakadu (modimo/medimo) & antbear & adult male only
\end{tabular}

Birds:

\begin{tabular}{|l|l|}
\hline leaka (lenong) & vulture \\
tlhantlhagane & siskin \\
tladi & lightning-bird or flamingo. (The greater flamingo is tladi; the lesser flamingo is tlaťsana.) \\
\hline
\end{tabular}

Objects:

\begin{tabular}{|l|l}
\hline legakadima (setumo) & rock crystal \\
letlapa la kgokolwana (tšhilo) & round stone \\
letlapa le leso (moleko) & black stone \\
koko ya lerula (meropa) & nut (of marula) \\
leweť̌a & a stone found in the entrails of a goat \\
\hline
\end{tabular}

It can be observed that some of the knuckle-bones have their own names, for example, the steenbok is malope, the cattle are maseselle, the sheep is serome, the antbear is modimo/medimo, the vulture is lenong, the rock crystal is setumo, the round stone is tšhilo, the black stone is moleko, and the nut (of the marula) is meropa. The names of such knuckle-bones are essential, because they are instrumental in the composition of a divinatory poem.

The antbear is the modimo (ancestor) of the diviners since it is a digger. There is an opposing belief in certain Bapedi clans that the antbear and the sea shells usually serve as representatives of the gods of the Europeans.

There are five pieces of divining bones which do not represent clans or groups of people. The sheep ( $n k u)$ represents females only, and the goat (pudi) represents both male and female, and these divining bones are related to rainmaking. The lightning-bird (tladi) (a toe-joint) is very important when the divining bones are consulted for weather prospects or is sometimes asked to point out a sorcerer who has sent lightning to destroy his enemy's property. It does not represent any gender. A stone found in the entrails of a goat (leweť̌a) is consulted in connection with internal ailments; it also does not represent any specific gender.

Some time has been devoted to discussing these divinatory objects as they recur in the poems of divination, which, in turn, need to be interpreted in the light of the embedded symbolism.

\section{Process of Sepedi divination}

A qualified diviner, in attempting to discover the cause of death, illness and misfortune or to learn whether some enterprise will prove successful, examines the Sepedi divining bones. In every case, when a person seeks advice from the diviner, the latter must consult the divining bones as part of the examination. Before the examination, the diviner must ask his/her ancestors to allow him/her to examine his/her patient and, then, contact between himself/ herself and the divining bones is believed to be established. To establish complete communication between the di- 
viner and his/her ancestors or the patient's ancestors, a praise poem related to a particular divination will be recited in honour of the dipheko (divinatory bones).

\section{Summary}

Most Sepedi traditional divinatory poems do not consist of verses or stanzas. Form designs (Simpson, 1972:5) of poetry of the divinatory bones are, to a large extent, bound up with what they were intended for (for communication with ancestors and not for performance before an audience in public gatherings), as well as the manner in which they were recited. For this reason, the conveyance of thought and action, embellished in various stylistic ways, is uppermost. Accordingly, such thoughts and actions are conveyed in the form of prayer rather than entertainment.

In this article, cultural verse designs in Sepedi poetry of divinatory bones have been examined and categorized under metrical compositions, long-measure verse, long-measure repetition verse, divinatory poems with linked hemistichs, and divinatory poems with repeated segments, long-measure triplet verses and verses of four, five or more hemistichs.

The diviner plays an essential role in the spiritual lives of the Bapedi. That is why his/her position in the society is highly honoured and respected and his/her influence and power are second only to a kgoši 'king' and his council. Consequently, the diviner, like any other traditional healer, is very important in the nation's activities. In the divination, the diviner uses a set of divinatory bones. In every case, when a patient seeks spiritual and physical advice from the diviner, the diviner must consult the divining bones for the examination. Before the examination, the diviner must address the question to his/her ancestors to allow him/her to examine his/her patient and then contact between himself/herself and the divining bones will be established. To establish complete communication between the diviner and his/her ancestors or the patient's ancestors, a praise poem related to a particular divination is recited in honour of the divinatory bones.

\section{Notes}

1. RSA Constitution, $1996: 4$

2. Even if selomi (carved bull's hoof, representing a male) is not mentioned by name in this divinatory poem, it is an elision, because divining bones are otherwise usually addressed in divinatory poetry.

3. The sign (/) stands for a short rest and (//) stands for a long one. In other words, this poem is divided into five hemistichs as indicated by the sign (/) and/or (//).

4. Tlou (elephant bone representing male, female and child) is mentioned by name in this divinatory poem, in accordance with the usual practice of addressing divining bones in divinatory poetry.

5. Moremogolo (more wo mogolo), refers to one of the divinatory bones, i.e. a carved cow's hoof representing a female.

\section{References}

Brooks, C. \& Warren, R.P. 1976. Understanding poetry. U.S.A.: Holt, Rinehart and Winston.

Brown, C.F. 1966. Introduction to metrics: The theory of verses. London: Mouton \& Co.

De Groot, A.W. 1946. Algemene versleer. Den Haag: N.V. Servire.

Eiselen, W.M. 1932. The art of divination as practised by the BaMasemola. Bantu Studies vi:1-29.

Groenewald, P.S. 1993. Thutadingwalo ya Sesotho sa Leboa 1 and 2. Pretoria: Via Afrika.

Guma, S.M. 1967. The form, content and technology of traditional literature in Southern Sotho. Pretoria: J.L. van Schaik.

Harries, L. 1956. Cultural verse-forms in Swahili. African Studies 15(4):176-187.

Heese, M. \& Lawton, R. 1983. The owl critic. Goodwood: Nasou Ltd.

Hymes, D.H. 1960. Part 4: Linguistics and poetics, in Style in language, edited by T.A. Sebeok. New York, London:

Technology Press, Wiley:109-131. 
Jakobson, R. 1960. Part 9: Phonological aspects of style: Some English sonnets, in Style in language, edited by T.A. Sebeok. New York, London: Technology Press, Wiley:350-377.

Mashilo, P.M., Mohlamonyane, J.N. \& Maripane, J.P. 1998. Mokaka' Kgomo 3. Pietermaritzburg: Shuter \& Shooter. Mojalefa, M.J. 2000. Sepedi 362, Lecture notes. Pretoria: University of Pretoria.

Mokgwadi, Johannes. 1999. The collection and recording of the traditional literary art of the Bapedi: A research project. Sound recording in Sekhukhune.

Opland, J. 1983. Xhosa oral poetry: Aspects of Black South African tradition. London: Cambridge University Press.

Republic of South Africa. 1996. The Constitution of the Republic of South Africa, Act 108 of 1996.

Rycroft, D.K. 1960. Melodic features in Zulu eulogistic recitation. African Language Studies 1:60-78.

Shipley, T.J. 1972. Dictionary of world terms. Boston: The Writer Inc.

Simpson, L.A.M. 1972. An introduction to poetry. New York: St. Martin's Press. 